UDC 336:658.1

JEL Classification: G11, G32

http://doi.org/10.21272/mmi.2018.4-24

\author{
Aleksandr Kljucnikov, \\ Ph.D., Associate Professor, University of Entrepreneurship and Law, Czech Republic \\ Monika Sobekova Majkova, \\ Ph.D., Pan-European University, Slovakia
}

\title{
FUNDING RISK PERCEPTION BY SLOVAK SMES: IMPACT OF AGE AND SIZE OF THE COMPANY
}

Abstract. Small and medium-sized enterprises are facing many types of business risks, almost unknown or unimportant for the large companies, where the funding risk plays an essential role due to the importance of the need of the external financial sources for their growth. This paper investigates the impact of a size of the company and an age of the owner on the perception of the funding risk in the segment of small and medium-sized enterprises in Slovakia in response to the restraints in their access to credit finance. The results of the research specify the importance of these factors in determining the scope of the funding risk exposure on Slovak SMEs. The paper is based on the data from the scientific research carried out in 2016 in Slovakia among 438 companies. The data were analyzed by Pearson's chi-square statistics, which allowed to confirm the existence of the statistically significant dependencies between the chosen factors and the perception of the funding risk. The presented statistical evidence confirms that the size of the company and the age of the owner are significant in relation to the funding risk of a company from the segment of SMEs. Smaller companies do perceive the funding risk more intensively than larger ones. The statistically significant impact of the selected factors on the frequency of bank loans rejection was confirmed only in case of the age of the owner, but not in case of the size of the company, when the entrepreneurs of the age between 36 and 45 declared the highest rejection rate of the loan applications. A surprising finding is that younger entrepreneurs are significantly more self-confident in case of the potentially negative influence of the funding risk on their companies than their older colleagues. The results of the research also confirm the existence of the statistically significant dependence between the selected factors and the reasons for the rejection of bank loans applications. We can declare that a credit rejection is most common in case of younger business owners but is not typical for the smaller companies. In the group of entrepreneurs aged between 36 and 45 years the most frequent reason was related to the negative values of the financial indicators, and in case of the oldest entrepreneurs the most often reasons of the rejection of the loan application were the lack of collateral, poor business plan and negative values of the financial indicators.

Keywords: credit risk, small and medium-sized enterprises, age, size, loan financing, bank financing, external finance, access to finance.

Introduction. Small and medium-sized enterprises (SMEs) belong to the specific segment of the economy that has several distinct characteristics, usually related to the size of the companies. The scale of SMEs' contribution to the economy makes them a backbone of each market economy (Cepel et al., 2018; Dobeš et al., 2017; Kozubíková et al., 2017; Sobeková, 2011, Mura and Gašparíková, 2010), and allows to consider them for one of the most important components of the world's economy (Karpak and Topcu, 2010, Badulescu, 2010). Henderson and Weiler, 2010, Hajduová et al., 2014 declare that SMEs are the most important engine of an economic growth. $99 \%$ of all companies in the USA and the European Union belong to the segment of SMEs (Bhaird, 2010). According to the data of the Slovak business agency, the number of SMEs in this country is exactly $99.9 \%$, while they create $50 \%$ of the state added value and are responsible for the employment of the $70 \%$ of the workforce. Despite their vital contribution to the economy, the companies from the segment of SMEs segment belong to the category of endangered economic species, mainly because of their size. These companies are facing many types of business risks, almost unknown or unimportant for the large companies, where the funding risk plays an essential role due to the importance of the need of the external sources of finance for the growth of SMEs (Bena

Cite as: Kljucnikov, A., \& Majkova, M. S. (2018). Funding Risk Perception by Slovak SMEs: Impact of Age and Size of the Company. Marketing and Management of Innovations, 4, 282-297. http://doi.org/10.21272/mmi.2018.4-24 
and Ondko, 2012, Ključnikov and Belás, 2016, Ključnikov et al. 2016a, Vojtovič, 2016, Ključnikov et al. 2016b, Mercieca et al., 2009, Mentel and Brożyna, 2015; Gambini a Zazzaro, 2013, etc.). SMEs often experience difficulties with the obtaining of the bank loans because of their weak capital power and a usually short history.

The aim of this paper is to investigate the impact of a size of the company and an age of the owner on the funding risk in the segment of small and medium-sized enterprises in Slovakia in response to the restraints in their access to credit finance. The paper has the following structure. The actual start of the art in this field of study identified through the literature research is described in the first chapter. The second chapter presents the research methodology and describes the research data. The results are presented in the third chapter and are discussed in the fourth one. The last chapter concludes the findings of the research.

Literature review. Funding risk is the possibility, that a company will be unable to execute its strategic plans due to the financial reasons, including an inability to gain sufficient value of financial sources neither by concentration of an additional equity, nor by the credit resources, or the cases of unacceptable increase of the price of these financial sources (Fetisovová et al., 2012). Bena and Ondko (2012) declared that an access to the external sources of finance is important for the companies with the growth potential in the developed countries. The claim that access to finance is necessary for the growth and further development of SMEs is concurrently confirmed by Mercieca et al. (2009) and Rabbani and Moosa (2014). According to Jakubec et al. (2012), insufficient financing is one of the most important barriers for young entrepreneurs. Steinerowska-Streb and Steiner (2014) declared that the lack of finance is considered to be the main reason for the limitation of the growth of SMEs. Italian researches Gambini and Zazzaro (2013) found that bank lending has a positive effect on the growth of companies. Behr a Guttler (2007) considered the bank lending for a dominant external financial source used by German SMEs.

Cheng, Tang and Shi (2012) confirmed the results of Majková (2008) by the finding that a weak capital power and a credit degree as the biggest problems of SME financing. Sobeková (2011) found that the usage of the internal sources of financing in case of SMEs in Slovakia is dominating over the external financial sources, including leasing and bank loans. She also stated that in case of the debt financing Slovak SMEs are mainly experiencing problems with the guarantees. While the economic crisis has reduced the profitability of SMEs in the Czech Republic and Slovakia (Belás et al, 2015), three quarters of the entrepreneurs in the segment of SMEs in the Czech Republic perceive the intense action of the financial risk, but at the same time their ability to properly manage financial risks in the segment of SMEs is not at an appropriate level (Belás et al., 2016; Kozubíková et al., 2017).

The funding risk, an important part of the financial risk of the company, is closely related to the expense of usage of the loan financing, the most frequent source of external capital in case of SMEs. But is the size of the company in the SME segment a significant factor, that is able to influence the intensity of the funding risk? SMEs are experiencing problems with many obstacles in doing business (Simo et al, 2016). Irwin and Scott (2010) identified an access to bank financing as a significant barrier for business development in case of SMEs in the UK. While larger companies do not usually experience the problems with the collateral in case of the bank financing because of the level and structure of their assets, companies from the SME segment are more vulnerable in this case. Bottazzi et al. (2014) stated that small companies have more limited options for external financing than larger ones. Bougheras et al. (2006) found that the size of the company matters in the relationship with the banks. Belas and Sopkova (2016) found that larger companies belonging to the segment of SMEs are more active and more autonomous in comparison to microenterprises. These findings indicate that the size of the company could be an important factor in the assessment of the funding risk.

According to Seo (2013), SMEs are unable to provide a sufficient amount of collateral more frequently in comparison with large enterprises. While based on the previous researches Seo (2013) hypothesized 
that the bank loans to SMEs are riskier in comparison with the loans to large companies, he found that the loans of smaller banks tend to be less responsive to the economic shock, which is in line with the largebank barriers hypothesis. Dong and Men (2014) confirmed that smaller and younger companies are facing more financing constraints. The availability of credit information and the bank concentration ratio have a significant impact on SME financing. Small and growing firms in Great Britain are likely to have higher interest rates in case of bank loans than large firms with the regular turnover. Rostamkalaei and Freel (2015) stated that the size of the company affects the interest rates values: the smaller the firm is, the higher the interest rates are. Also, Oliveira and Fortunato (2006) considered the size of the company for a relevant factor. They presented the finding that the credit rejection or high-interest rates are most common in case of the small companies.

The age of the owner is the next discussed factor with the influence on the funding risk. The general impact of age on business was declared by many authors. Arenius and Minniti (2005) examined the influence of the demographic factors, including the age, gender and level of education on the willingness of an individual to become an entrepreneur, and according to the results of their research, the age is negatively related to entrepreneurship. The positive impact of age on business was declared by the other authors. Bonte, Falck and Heblich (2007) examined the relationship between the age structure and business startups in the western part of Germany. They considered the age as one of the most important factors for becoming an entrepreneur. Brunow and Hirte (2006) examined an impact of age on the regional economic growth. Levesque and Minniti (2011) bring a statistical evidence that the age has an impact on the entrepreneurial growth. According to Lazányi (2014), young entrepreneurs and tertiary students have a lack of entrepreneurial competencies in comparison with the older and more mature entrepreneurs.

The number of studies, related to the impact of age on the credit risk of a company is quite limited. Such authors as Bougheas et al. (2006), Bottazzi et al. (2014), Dong and Men (2014), HernándezCánovas and Martínez-Solano (2010), Lazányi (2014), Oliveira and Fortunato (2006), Pickernell et al. (2011), Riding et al. (2012) Vos et al. (2007), declare that the funding risk is highly related to the age of an entrepreneur, while it is substantially higher in the group of younger entrepreneurs. Sobeková Majková (2016) brought statistical evidence that the age has a significant impact on the ability of the company to protect against the change of the interest rate and that young entrepreneurs have problems with obtaining capital and increasing interest rates and collaterals because of their higher risk profile.

Different authors state that the age of the owner influences the financing of the company, and therefore may influence the perception of the funding risk. Vos et al. (2007) brought a significant finding that young entrepreneurs do take loans according to their age. According to their study, younger and less educated entrepreneurs are more likely to use external financing sources to finance the growth of their businesses, while older and more educated entrepreneurs are more focused on the internal financial sources. The research by Colombo et al. (2016) identified that younger companies suffer from the financing constraints, directly related to the funding risk, sufficiently more than the older and more experienced ones, which limits their growth. The results of Neuberger and Räthke-Döppner (2014) from Germany confirm that due to the smaller size of business, lower level of liquidity and therefore higher probability of the delay of payments to the suppliers, young entrepreneurs are more likely to pay higher interest rates than their older colleagues. Oliveira and Fortunato (2006) in their research focused on Portuguese entrepreneurs found that the rejection of the loan or higher interest rates are most common in case of small and young firms. According to their results, small and young entrepreneurs are highly cash-flow sensitive, which is causing their financial restraints to be more substantial than in the case of the larger firms. Werner and Faulenbach (2008) confirmed that age has an impact on the funding risk, resp. that young entrepreneurs are facing the funding risk more often than older entrepreneurs. They found that older entrepreneurs have fewer problems in getting a start-up capital than the younger ones. Coleman et al. (2014) devoted their study to the impact of age of the owner on the composition of start-up capital of the companies and found the age 
to be a significant factor. They found that younger companies are more likely to focus on less formal (and more expensive) financial sources, often due to the inability to provide a sufficient collateral to secure the loan. The impact of age on funding risk is also declared by Bottazzi et al. (2014) and Bougheas et al. (2006). They brought the evidence that the age influences the relationship with the banks and influences the options of external financing. Even if the majority of the researches declare the significant impact of age on the financial risk, some authors present the opposite results. For instance, Slavec (2014) in his research of Slovenian SMEs has found no significant impact of the age of the business owner on the bank loans or trade credits.

Research Methodology and Scientific Methods of Survey. This part of the paper describes the scientific methods used in our research, the way of data collection, the characteristics and size of the data sample, and provides information about alternative working hypotheses. The research focused on the actual situation in the Slovak business environment was carried out in 2016. The questionnaire called Financial Risks of SMEs in Slovakia was distributed online and is available on the link: https://docs.google.com/forms/d/1Fhob6avbfQq4DcaYG44mxNYyohzcqZWDICXkUgFbNq4/ viewform? $=0 \& w=1$.

The research data were collected in three specific ways. First of all, a random selection of the appropriate companies was made from the free database of Slovak companies available on www.vsetkyfirmy.sk. The selected companies were contacted by our research team by email. In case that the selected company did not react on the email, it was contacted by phone. The questionnaire was also placed on the specialized economic web-portals, focused on SMEs. Finally, the sample of the companies selected by the team experts was contacted directly by the researchers. The total number of 438 questionnaires was collected during the research. This number of respondents fulfils the requirements for stochastic selection. Our research team defined four groups of monitored enterprises in relation to the size of the company according to the European Union Directive, where the main criterion for the aggregation was the number of employees: micro companies employ 0 to 9 employees, small companies 10 to 49 employees, middle-sized companies from 50 to 249 employees and big companies employ more than 250 of them. According to the newest official Slovak statistical data presented in the report of the Slovak business agency (Table 1) 531.063 of small and medium-sized enterprises were operating in Slovakia in 2015.

Table 1 - The number of companies and SMEs in Slovakia in 2015

\begin{tabular}{|l|c|c|c|c|}
\hline \multirow{2}{*}{ Legal Form (2015) } & \multicolumn{2}{c|}{ Basic data set } & \multicolumn{2}{c|}{ Selected sample } \\
\cline { 2 - 5 } & Total values & Share (\%) & Absolute values & in \% \\
\hline $\begin{array}{l}\text { Micro enterprises (0-9 emp.) and } \\
\text { individual entrepreneurs }\end{array}$ & 515236 & $96.9 \%$ & 287 & $65.6 \%$ \\
\hline Small enterprises (10-49 emp.) & 12984 & $2.4 \%$ & 95 & $21.7 \%$ \\
\hline Medium enterprises (50-249 emp.) & 2843 & $0,5 \%$ & 29 & $6.6 \%$ \\
\hline Large enterprises (250+ emp.) & 666 & $0.1 \%$ & 27 & $6.2 \%$ \\
\hline Total number of business units & 531729 & $100 \%$ & 438 & $100 \%$ \\
\hline SMEs from total & 531063 & & 411 & \\
\hline Share of SMEs in \% & $99.9 \%$ & & $93.8 \%$ & \\
\hline
\end{tabular}

Sources: Slovak Business Agency (2016): SMEs Report 2015, own processing

According to the calculated sample, the research team assumes that the data are representative and have the reliability of $95 \%$. The sampling error of $+/-5 \%$ should be considered. The minimum size of the sample should be calculated according to the formula $n=(1.96)^{2} \times \sqrt{ } p \times(1-p) / 0.05^{2}$ where $p$ is the share of the sample. The size of the minimum sample was 310 , while the real size of our sample was 438 . 
The comparison of the different characteristics of the basic data set and our selected sample indicates striking similarities, while the differences between them are insignificant. For instance, the basic dataset contains $99.8 \%$ of SMEs, while our sample contains $93.8 \%$ of them (the difference is only $6.1 \%$ ); the data about the regional structure and the area of primary economic activity of the selected companies are also close to each other.

In order to analyze the data and evaluate the results our research team used the tools of descriptive statistics (averages and percentage), Microsoft Excel (Office 2007) software as an important tool for data analysis due to its possibilities in data processing using the pivot tables, and the methods of comparison and deduction in data analysis. However, the aim of the paper is to examine the dependencies between the two variables we decided to use a statistical method of Pearson's chi-square by using the statistical software available at www.socscistatistics.com to confirm the significance of the identified relations. This method allows to confirm the statistical results at $50 \%$ level of significance level and provides a simple verification of the existence of the statistically significant dependences and differences between the selected factors.

By the method of expert estimation, we have defined five alternative working hypotheses $(\mathrm{H} 1-\mathrm{H} 5)$ related to the chosen factors. The accuracy of the hypotheses was verified by the statistical methods. Each hypothesis included two parts - one in relation to the size of the company and the second in relation to the age of the owner. Null hypotheses assuming there are no statistically verifiable differences between the observed groups were supplementing the alternative hypotheses. Null hypotheses: There are no statistically significant dependencies between the chosen factors (size/age) and the chosen aspects of the funding risk.

Null hypothesis: $\pi_{1}=\pi_{2}$ so $\pi_{1}=\pi_{2}=0$. Alternative hypothesis: $\pi_{1}=\pi_{2} \neq 0$. Five alternative working hypotheses were defined as follows:

$\mathrm{H} 1$ : There is a statistically significant dependence between the size of the company and/or the age of the owner and the opinion that the importance of funding risk has increased over the past three years. We suppose that smaller firms perceive the influence of the funding risk more intensively in comparison to the larger enterprises, and younger owners in comparison to the older ones.

$\mathrm{H} 2$ : The size of the company and/or the age of the owner has a statistically significant impact on the opinion that the banks accept the needs of the companies and try to do their best to meet their expectations. We suppose that the banks present a better approach to the larger companies, and to the older owners.

H3: There is a statistically significant dependence between the size of the company and/or the age of the owner and frequency of the rejection of the bank loans. We assume that banks reject the loan applications of smaller firms and of the younger owners more often.

H4: The size of the company and/or the age of the owner has a statistically significant impact on the reasons for the rejection of a loan application. We assume smaller companies, and/or the companies owned by the younger owners more frequently experience the problems with the short history of the company and an insufficiency of the collateral.

H5: The size of the company and/or the age of the owner has a statistically significant impact on the expression of the opinion that it is difficult to meet loan conditions, and the opinion that SMEs in the other EU countries have better loan conditions than SMEs in Slovakia.

The results of the research. The third chapter of the paper is divided into 5 parts, where each one is focused on the rejection of confirmation of the selected alternative hypothesis in relation to the chosen factors. The hypotheses, related to the first analyzed factor - the age of the owner - are marked by the letter $\mathrm{a}$, and the hypotheses, related to the second analyzed factor - the size of the company - is marked by the letter $\mathrm{b}$. Also, the working hypothesis is marked as $\mathrm{H} 1 \mathrm{a}, \mathrm{H} 1 \mathrm{~b}, \mathrm{H} 2 \mathrm{a}$, etc......H5b. An impact of the selected factors on the change of importance of the funding risk. At first, we have investigated the impact 
of the size of the company and the age of the owner on the funding risk of the company, specifically on the opinion that the importance of funding risk has increased over the past three years. The results presented in Table 2 confirm the existence of a statistically significant dependence between the age of the owner and the perception of the funding risk of Slovak companies. According to the findings, older entrepreneurs are more concerned about the funding risk than their younger colleagues. The differences were identified between the group of entrepreneurs younger than 35 years $(47.24 \%$ of them agree with the opinion that the importance of the funding risk has increased over the past three years) and older than 35 years ( $64 \%$ of them agreed with this statement).

Table 2 - The age of the owner and the importance of the funding risk*

\begin{tabular}{|c|c|c|c|c|c|c|c|c|}
\hline $\begin{array}{c}\text { An } \\
\text { importance } \\
\text { of funding } \\
\text { risk has } \\
\text { increased } \\
\text { over the } \\
\text { past three } \\
\text { years }\end{array}$ & $\%$ & $\begin{array}{c}\text { Agree } \\
\text { absolute values } \\
\text { and chi-square } \\
\text { subtotals }\end{array}$ & $\%$ & $\begin{array}{c}\text { Disagree } \\
\text { absolute values } \\
\text { and chi-square } \\
\text { subtotals }\end{array}$ & $\%$ & $\begin{array}{c}|c| \\
\text { absolute values } \\
\text { and chi-square } \\
\text { subtotals }\end{array}$ & $\%$ & $\begin{array}{c}\text { Neutral position } \\
\text { lute } \\
\text { val- } \\
\text { ues }\end{array}$ \\
\hline To 35 years & 47.24 & $77(93.78)[3.00]$ & 11.66 & $19(19.72)[0.03]$ & 41.10 & $67(49.50)[6.19]$ & 100 & 163 \\
\hline $36-45$ years & 66.67 & $76(65.59)[1.65]$ & 15.79 & $18(13.79)[1.28]$ & 17.54 & $20(34.62)[6.17]$ & 100 & 114 \\
\hline 46 and more & 61.49 & $99(92.63)[0.44]$ & 9.94 & $16(19.48)[0.62]$ & 28.57 & $46(48.89)[0.17]$ & 100 & 161 \\
\hline Total & - & $\mathbf{2 5 2}$ & - & $\mathbf{5 3}$ & - & $\mathbf{1 3 3}$ & $\mathbf{1 0 0}$ & $\mathbf{4 3 8}$ \\
\hline
\end{tabular}

${ }^{*}$ Grand total in chi-square calculation

\section{Sources: own processing}

The results of the calculations (Table 2) confirm our assumption of the statistically significant dependence between the age of the owner and the perception of the funding risk of the Slovak companies. The value of chi-square statistic $x^{2}=19.5571=x^{2} 0,01$ with 4 dgf (Degrees of freedom) and the $p$-value of 0.000611 indicate that the result is significant at $p<0.01$. This fact allows us to confirm our alternative working hypothesis $\mathrm{H} 1 \mathrm{a}$ with the level of probability of $99 \%$. The second part (b) of the hypothesis $\mathrm{H} 1$ was devoted to the impact of the size of the company on the opinion that the importance of funding risk has increased over the past three years. We supposed that smaller firms perceive the influence of the funding risk more intensively in comparison to the larger enterprises. We have found a statistically significant dependence between the size of the company and the expressed opinion in relation to the defined statement, which confirms that smaller companies do perceive the funding risk more intensively than larger companies. Our evidence shows that while $58.67 \%$ of the representatives of the companies from the SMEs segment perceives that the importance of the funding risk has increased over the past three years, only $55,56 \%$ of the representatives of the large companies agree with the statement. It is interesting, that the lowest level of interest in relation to the funding risk was presented by the representatives of the micro-enterprises, the segment that should be the most vulnerable in case of funding. We consider that the fact that micro companies do not perceive the importance of the funding risk so intensely can be reasoned by a lower level of usage of bank loans for their financing.

The results of the calculations presented in Table 3 allow us to confirm the hypothesis $\mathrm{H} 1 \mathrm{~b}$ about the statistically significant dependence between the size of the company and the perception of the funding risk of the Slovak companies at the level of probability of $99 \%$. The value of chi-square statistic $x^{2}=21.7351=x^{2} 0,05$ with 6 dgf. and the $p$-value of 0.001352 indicates that the result is significant at $p<0.01$. 
Table 3 - The size of the company and the importance of the funding risk

\begin{tabular}{|l|c|c|c|c|c|c|c|c|}
\hline $\begin{array}{c}\text { An } \\
\text { importanc } \\
\text { e of } \\
\text { funding } \\
\text { risk has } \\
\text { increased } \\
\text { over the } \\
\text { past three } \\
\text { years }\end{array}$ & $\%$ & $\begin{array}{c}\text { Agree } \\
\text { absolute values } \\
\text { and chi-square } \\
\text { subtotals }\end{array}$ & $\%$ & $\begin{array}{c}\text { Disagree } \\
\text { absolute values } \\
\text { and chi-square } \\
\text { subtotals }\end{array}$ & $\%$ & $\begin{array}{c}\text { Neutral position } \\
\text { absolute values } \\
\text { and chi-square } \\
\text { subtotals }\end{array}$ & $\%$ & $\begin{array}{c}\text { Total } \\
\text { abso- } \\
\text { lute } \\
\text { val- } \\
\text { ues }\end{array}$ \\
\hline Micro & 56.79 & $163(165.12)[0.03]$ & 7.67 & $22(34.73)[4.67]$ & 35.54 & $102(87.15)[2.53]$ & 100 & 287 \\
\hline Small & 60.00 & $57(54.66)[0.10]$ & 18.95 & $18(11.50)[3.68]$ & 21.05 & $20(28.85)[2.71]$ & 100 & 95 \\
\hline Medium & 58.62 & $17(16.68)[0.01]$ & 24.14 & $7(3.51)[3.47]$ & 17.24 & $5(8.81)[1.64]$ & 100 & 29 \\
\hline Large & 55.56 & $15(15.53)[0.02]$ & 22.22 & $6(3.27)[2.29]$ & 22.22 & $6(8.20)[0.59]$ & 100 & 27 \\
\hline Total & - & 252 & - & 53 & - & 133 & 100 & 438 \\
\hline
\end{tabular}

\section{Sources: own processing}

An impact of the selected factors on the perception of the relationships with the banks. Our research results do not bring any statistically significant evidence about the existence of the dependency between the age of the owner and the expression of the opinion that the banks accept the needs of the companies and try do their best to meet their expectations. General results show that most of the business owners regardless of their age are quite a sceptic about the effort of the banks to accept their needs. Only approximately one-third of the respondents $(30.67-38.60 \%)$ in each age category agreed with the presented statement, while almost half of them (45.96 - $48.25 \%)$ disagreed with it. Middle-aged entrepreneurs (36-45-year-old) are the most optimistic. Younger and older groups were more pessimistic. The results of the research presented in Table 4 do not confirm the assumption from the hypothesis $\mathrm{H} 2 \mathrm{a}$ about the statistically significant dependence between the age of the owner and the opinion that banks accept the needs of the companies. The value of chi-square statistic $x^{2}=5.5064=x^{2} 0,05$ with 4 dgf. and the $p$-value of 0.239164 allows us to reject our working alternative hypothesis $\mathrm{H} 2 \mathrm{a}$.

Table 4 - The age of the owner and the relationships with the banks

\begin{tabular}{|c|c|c|c|c|c|c|c|c|}
\hline \begin{tabular}{c} 
Banks \\
accept the \\
needs of \\
the \\
\cline { 2 - 9 }
\end{tabular} \\
$\begin{array}{c}\text { entrepreneu } \\
\text { rs and try to } \\
\text { meet them }\end{array}$ & $\%$ & $\begin{array}{c}\text { absolute values } \\
\text { and chi-square } \\
\text { subtotals }\end{array}$ & $\%$ & $\begin{array}{c}|c| \\
\text { absolute values } \\
\text { and chi-square } \\
\text { subtotals }\end{array}$ & $\%$ & $\begin{array}{c}\text { Disagree } \\
\text { absolute values } \\
\text { and chi-square } \\
\text { subtotals }\end{array}$ & $\%$ & $\begin{array}{c}\text { abso- } \\
\text { lute } \\
\text { val- } \\
\text { ues }\end{array}$ \\
\hline To 35 years & 30,67 & $50(53.59)[0.24]$ & 46,63 & $76(76.29)[0.00]$ & 22,70 & $37(33.12)[0.45]$ & 100 & 163 \\
\hline $\begin{array}{c}36-45 \\
\text { years }\end{array}$ & 38,60 & $44(37.48)[1.13]$ & 48,25 & $55(53.36)[0.05]$ & 13,16 & $15(23.16)[2.88]$ & 100 & 114 \\
\hline 46 and more & 31,06 & $50(52.93)[0.16]$ & 45,96 & $74(75.35)[0.02]$ & 22,98 & $37(32.71)[0.56]$ & 100 & 161 \\
\hline Total & - & 144 & - & 205 & - & 89 & 100 & 438 \\
\hline
\end{tabular}

\section{Sources: own processing}

The next partial aim was to evaluate the impact of the size of the company. The research team assumed that with the increase of the size of the company the frequency of the occurrence of the consent 
with the statement that banks accept the needs of the companies and try do their best to meet their expectations will increase. The results, presented in Figure 1 confirm this assumption, while only $26.83 \%$ of the micro companies agreed with the statement, in case of the large companies the consent was presented by $62.96 \%$ of them, and the share was growing correspondingly with the growing size of the companies.

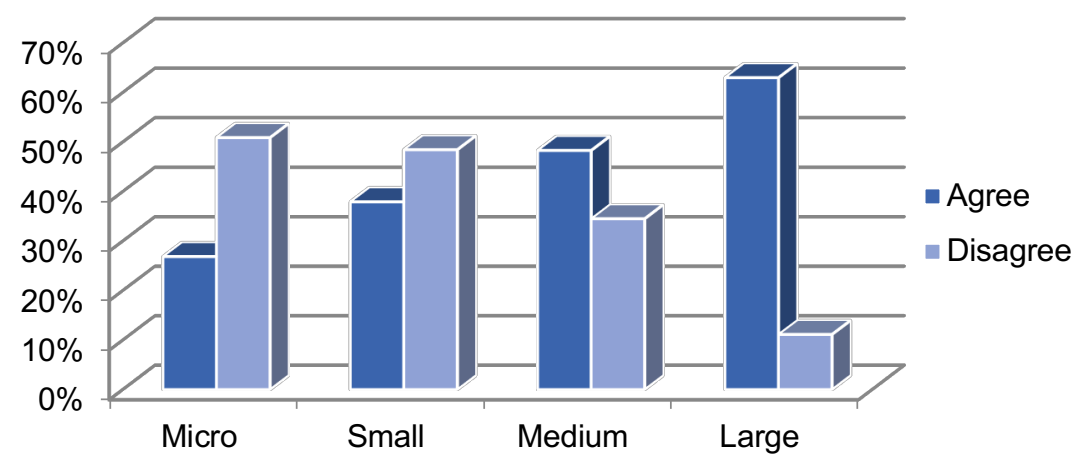

Figure 1 - Reactions on the statement that banks accept the needs of the companies in $\%$

\section{Sources: own processing}

The results of the calculations presented in Table 5 allow us to confirm the hypothesis $\mathrm{H} 2 \mathrm{~b}$, stating that the size of the company has a statistically significant impact on the opinion that the banks accept the needs of the companies and try to do their best to meet their expectations at the level of probability of $99 \%$.

Table 5 - The size of the company and the relationships with the banks

\begin{tabular}{|c|c|c|c|c|c|c|c|c|}
\hline $\begin{array}{c}\text { Banks } \\
\text { accept the } \\
\text { needs of } \\
\text { the } \\
\text { entrepren } \\
\text { eurs and } \\
\text { try to } \\
\text { meet } \\
\text { them }\end{array}$ & $\%$ & $\begin{array}{c}\text { Agree } \\
\text { absolute values } \\
\text { and chi-square } \\
\text { subtotals }\end{array}$ & $\%$ & $\begin{array}{c}\text { Disagree } \\
\text { absolute values } \\
\text { and chi-square } \\
\text { subtotals }\end{array}$ & $\%$ & $\begin{array}{c}\text { Neutral position } \\
\text { absolute values } \\
\text { and chi-square } \\
\text { subtotals }\end{array}$ & $\%$ & $\begin{array}{c}\text { Total } \\
\text { abso- } \\
\text { lute } \\
\text { val- } \\
\text { ues }\end{array}$ \\
\hline Micro & 26,83 & $77(94.36)[3.19]$ & 50,87 & $146(134.33)[1.01]$ & 22,30 & $64(58.32)[0.55]$ & 100 & 287 \\
\hline Small & 37,89 & $36(31.23)[0.73]$ & 48,42 & $46(44.46)[0.05]$ & 13,68 & $13(19.30)[2.06]$ & 100 & 95 \\
\hline Medium & 48,28 & $14(9.53)[2.09]$ & 34,48 & $10(13.57)[0.94]$ & 17,24 & $5(5.89)[0.14]$ & 100 & 29 \\
\hline Large & 62,96 & $17(8.88)[7.43]$ & 11,11 & $3(12.64)[7.35]$ & 25,93 & $7(5.49)[0.42]$ & 100 & 27 \\
\hline Total & - & 252 & - & 53 & - & 133 & 100 & $438^{*}$ \\
\hline
\end{tabular}

${ }^{*}$ Grand total in chi-square calculation

\section{Sources: own processing}

The value of chi-square statistic $x^{2}=25.9681=x^{2} 0,01$ with 6 dgf. and the $p$-value of 0.000226 indicates that the result is significant at $p<0.01$. An impact of the selected factors on the frequency of 
bank loans rejection. At this part of the research, our team focused on the impact of the age of the owner on the frequency of bank loans rejection, and a confirmation or a rejection of the hypothesis $\mathrm{H} 3 \mathrm{a}$. The results, presented in Table 6, confirm the existence of the statistically significant dependence between the age of the owner and a rejection of bank loan.

Table 6 - The age of the owner and the frequency of bank loans rejection

\begin{tabular}{|c|c|c|c|c|c|c|}
\hline $\begin{array}{c}\text { The bank } \\
\text { rejected our } \\
\text { loan application } \\
\text { within the past } \\
\mathbf{5} \text { years }\end{array}$ & $\%$ & $\begin{array}{c}\text { Yes } \\
\text { absolute values } \\
\text { and chi-square } \\
\text { subtotals }\end{array}$ & $\%$ & $\begin{array}{c}|c| \\
\text { absolute values } \\
\text { and chi-square } \\
\text { subtotals }\end{array}$ & $\%$ & $\begin{array}{c}\text { Absolute } \\
\text { values }\end{array}$ \\
\hline To 35 years & 30.06 & $50(53.59)[0.24]$ & 69.94 & $76(76.29)[0.00]$ & 100.00 & 163 \\
\hline 36 - 45 years & 39.47 & $44(37.48)[1.13]$ & 60.53 & $55(53.36)[0.05]$ & 100.00 & 114 \\
\hline 46 and more & 24.84 & $50(52.93)[0.16]$ & 75.16 & $74(75.35)[0.02]$ & 100.00 & 161 \\
\hline Total & - & 144 & - & $\mathbf{2 0 5}$ & 100,00 & 438 \\
\hline
\end{tabular}

Sources: own processing

Entrepreneurs of the age between 36 and 45 declared the highest rejection rate of the loan applications (39.47\%) in comparison with the other two groups of entrepreneurs (younger than 35 and older than 46). The reason for this may be a higher range of usage of bank financing in case of this group of entrepreneurs. The results of the calculations presented in Table 6 confirm our assumption about the existence of a statistically significant dependence between the age of the owner and the frequency of bank loans rejection. The value of chi-square statistic $x^{2}=6.7612=x^{2} 0,05$ with 2 dgf. and the $p$-value of 0.034027 indicates that the result is statistically significant at $p<0.05$. This fact allows us to confirm our alternative working hypothesis $\mathrm{H} 3 \mathrm{a}$ at the level of probability of $95 \%$.

While investigating the impact of the size of the company on the frequency of bank loans rejection during the last 5 years we found that despite the seeming existence of such a dependence, application of the statistical methods discourages this assumption. In spite of the fact, that large companies declared the highest rate of bank loans rejection, the value of chi-square statistic (Table 7) $x^{2}=2.1131=x^{2} 0,05$ with 3 dgf. and the p-value is 0.54971 allow us to reject an alternative working hypothesis $\mathrm{H} 3 \mathrm{~b}$.

Table 7 - The size of the company and the frequency of bank loans rejection

\begin{tabular}{|l|c|c|c|c|c|c|}
\hline $\begin{array}{c}\text { The bank } \\
\text { rejected our } \\
\begin{array}{c}\text { loan application } \\
\text { within the past 5 } \\
\text { years }\end{array}\end{array}$ & $\%$ & $\begin{array}{c}\text { Yes } \\
\text { absolute values and } \\
\text { chi-square subtotals }\end{array}$ & $\%$ & $\begin{array}{c}\text { Not } \\
\text { absolute values and chi- } \\
\text { square subtotals }\end{array}$ & $\%$ & $\begin{array}{c}\text { Total } \\
\text { absolute } \\
\text { values }\end{array}$ \\
\hline Micro & 31,01 & $89(87.80)[0.02]$ & 68,99 & $198(199.20)[0.01]$ & 100.00 & 287 \\
\hline Small & 28,42 & $27(29.06)[0.15]$ & 71,58 & $68(65.94)[0.06]$ & 100.00 & 95 \\
\hline Medium & 24,14 & $7(8.87)[0.40]$ & 75,86 & $22(20.13)[0.17]$ & 100.00 & 29 \\
\hline Large & 40,74 & $11(8.26)[0.91]$ & 59,26 & $16(18.74)[0.40]$ & 100.00 & 27 \\
\hline \multicolumn{1}{|c|}{ Total } & - & 144 & - & 205 & 100,00 & 438 \\
\hline
\end{tabular}

Sources: own processing

Hypothesis $\mathrm{H} 3$ was partially confirmed. The statistically significant impact of the selected factors on the frequency of bank loans rejection was confirmed only in case of the age of the owner, but not in case of the size of the company. We can declare that a credit rejection is most common in case of younger 
business owners, but is not typical for the smaller companies.

An impact of the selected factors on the reasons for a loan application rejection. A total of 144 companies in our research declared their experience with the rejection of bank loan application. There can be many reasons for the rejection of loan applications. We assumed that in case of the youngest entrepreneurs the most frequent reason for the rejection would be a short company history or a problem with lack of collateral.

The results, presented in Figure 2 confirmed our assumption. In case of the entrepreneurs up to 35 years old (the youngest respondents), the most frequent reason of the rejection was a short history of the company and the second most common reason was the lack of collateral. In the group of entrepreneurs aged between 36 and 45 years the most frequent reason was related to the negative values of the financial indicators, and in case of the oldest entrepreneurs the most often reasons of the rejection of the loan application were the lack of collateral, poor business plan and negative values of the financial indicators. The results of the research confirm the existence of the statistically significant dependence between the age of the owner and the reasons for the rejection of bank loans application. The value of chi-square statistic $x^{2}=15.2197=x^{2} 0,05$ with $6 \mathrm{dgf}$. and the $p$-value of 0.018615 indicates that the result is statistically significant at $p<0.05$. This fact allows us to confirm our alternative working hypothesis $\mathrm{H} 4 \mathrm{a}$ at the level of probability of $95 \%$.

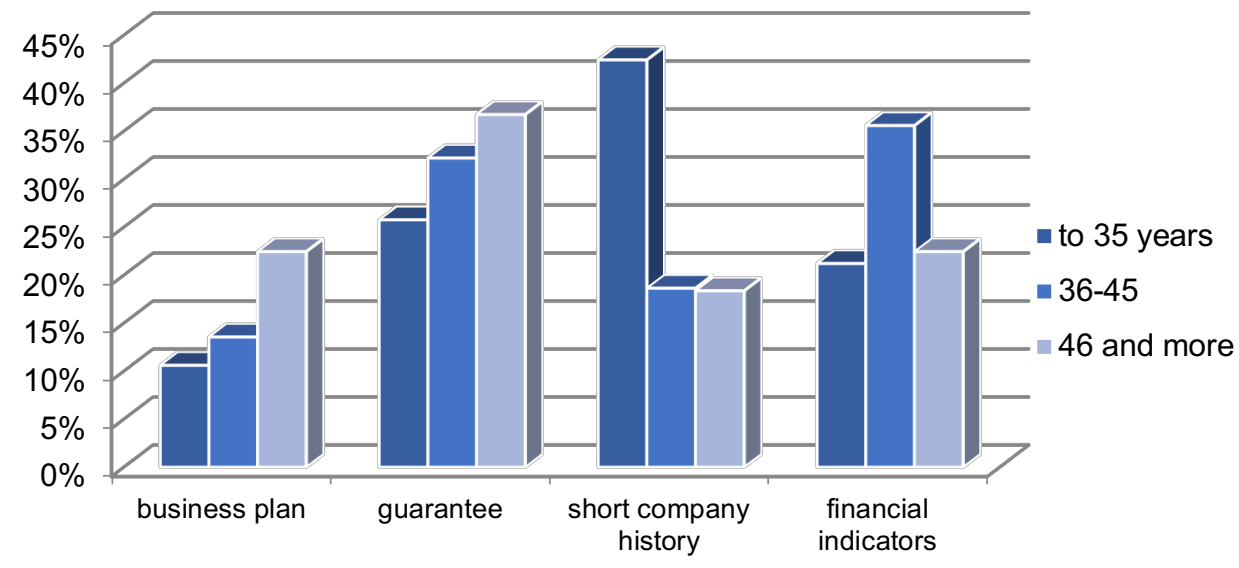

Figure 2 - Reasons for the rejection of bank loan application for the different age groups in $\%$

\section{Sources: own processing}

The second part of the hypothesis H4b was devoted to the impact of the size of the company on the reasons of the rejection of bank loans application. Application of the research methodology brought several interesting findings.

We found that the reasons for the rejection of bank loans application were different for the companies in each size group (Figure 3). In the group of micro companies, the most frequent reasons were the absence of the collateral (36.63 \%) and a short history of a company (32.67 \%). In the group of small companies, the most frequent reason of the rejection was related to the negative values of the financial indicators (35.90\%), a lack of collateral and a short history (both $23.08 \%$ ). Middle-sized companies pointed out a lack of collateral (38.46\%), negative values of the financial indicators $(30.77 \%)$, and large 
companies mentioned negative values of the financial indicators $(52.38 \%)$ and inadequate business plan $(19.05 \%)$ and the most frequent reasons for the rejection of their loan applications.

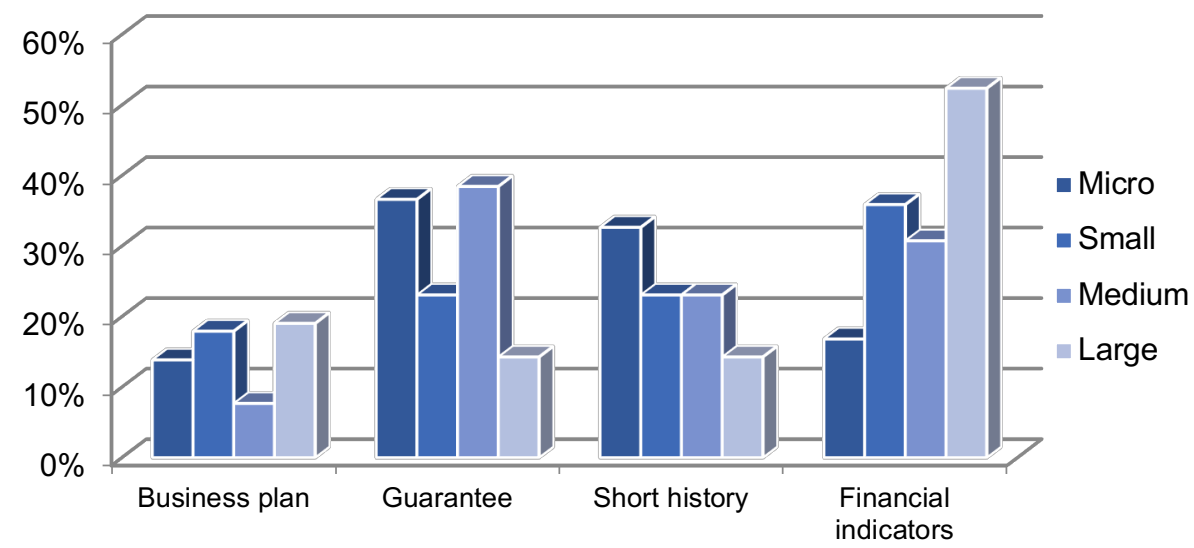

Figure 3 - Reasons for the rejection of bank loan application for the companies of the different size in $\%$

\section{Sources: own processing}

After the summarization of the results, we have specified the most significant reasons for the rejection of bank loans application: SMEs - lack of collateral and a short company history, large companies negative values of the financial indicators, inadequate business plan. The value of chi-square statistic $x^{2}=17.9159=x^{2} 0,05$ with 9 dgf. and the $p$-value of 0.036162 confirmed the statistical significance of the results at $p<0.05$. This fact allows us to confirm alternative working hypothesis $\mathrm{H} 4 \mathrm{~b}$ at the level of probability of $95 \%$.

The results of our research confirm the evidence of the other authors, who declared a collateral as one of the most often problems for the obtaining of a bank loan in case of SMEs (Irwin and Scot 2010, Seo, 2013 and Majková 2008).

An impact of the selected factors on the reasons for a loan application rejection on the other aspects of the funding risk. In the last part of this paper we bring the results of the research whether the size of the company and/or the age of the owner has a statistically significant impact on the expression of the opinion that it is difficult to meet loan conditions, and the opinion that SMEs in the other EU countries have better loan conditions than SMEs in Slovakia.

We found no statistically significant evidence of the significant impact of the age of the owner on the other aspects of the funding risk. The results of the research, presented in Table 8 do not bring a statistically significant evidence that the age of the owner has an impact on these two other aspects of the funding risk of SMEs in Slovakia. In both cases were the p-values were $>0.05$. An alternative working hypotheses $\mathrm{H} 5 \mathrm{a}$ was rejected.

The opposite results were found in case of the size of the company, while the results of the calculations by Pearson's chi-square indicate that the size of the company is a relevant factor. According to the percentage evaluation, almost two-thirds of the respondents $(63.51 \%)$ agree with the opinion that it is difficult to meet loan conditions in Slovakia. It means that Slovak companies perceive the loan conditions as difficult to fulfil. It is an interesting finding that nearly a half of the respondents (46.13\%) agree with the opinion that the companies in the other EU countries do have a better/easier loan conditions in comparison 
to Slovakia. On the other hand, we bring a statistical evidence about the impact of the size of the company in relation to the other aspects of the funding risk. Since the p-values in both cases are lower than 0.05 , we can confirm an alternative working hypotheses $\mathrm{H} 5 \mathrm{~b}$. Our results confirm the existence of a statistically significant dependence between the size of the company and the opinion that it is difficult to meet the loan conditions, and also between the size of the company and the opinion that SMEs in the other EU countries do have better loan conditions.

Discussion. The third part of this paper presented the results of the research on the impact of the specific factors on several aspects of the funding risk in case of SMEs in Slovakia. These results bring the evidence that the size of the company is a factor with a stronger impact on the funding risk than the age of the entrepreneur. The significant impact of the size of the company was confirmed in five cases out of six observations, and the impact of the age of the owner was confirmed only in three cases.

Table 8 - Summary of the results of the hypotheses $\mathrm{H} 1-\mathrm{H} 5$

\begin{tabular}{|l|c|c|c|c|}
\hline \multicolumn{1}{|c|}{ Hypotheses/questions } & \multicolumn{2}{|c|}{ Impact of the age } & \multicolumn{2}{c|}{ Impact of the size } \\
\cline { 2 - 5 } & Chi-square & $\boldsymbol{p}$-value & Chi-square & $\boldsymbol{p}$-value \\
\hline $\begin{array}{l}\text { H1: The importance of funding risk has } \\
\text { increased over the past three years }\end{array}$ & 19.5571 & $\underline{\mathbf{0 . 0 0 6 1 1 < 0 . 0 1}}$ & 21.7351 & $\underline{\mathbf{0 . 0 0 1 3 5 2 < 0 . 0 1}}$ \\
\hline $\begin{array}{l}\text { H2: The banks accept the needs of the } \\
\text { companies and try to meet their } \\
\text { expectations }\end{array}$ & 5.5064 & 0.239164 & 25.9681 & $\underline{\mathbf{0 . 0 0 0 2 2 6 < 0 . 0 1}}$ \\
\hline $\begin{array}{l}\text { H3: Frequency of the rejection of the bank } \\
\text { loans }\end{array}$ & 6.7612 & $\underline{\mathbf{0 . 0 3 4 0 2 7 < 0 . 0 5}}$ & 2.1131 & 0.54971 \\
\hline $\begin{array}{l}\text { H4: Reasons for the rejection of a loan } \\
\text { application }\end{array}$ & 15.2197 & $\underline{\underline{\mathbf{0 . 0 1 8 6 1 5 < 0 . 0 5}}}$ & 17.9159 & $\underline{\mathbf{0 . 0 3 6 1 6 2 < 0 . 0 5}}$ \\
\hline H5a: It is difficult to meet loan conditions & 5.9892 & 0.199958 & 16.6106 & $\underline{\mathbf{0 . 0 1 0 8 2 6 < 0 . 0 5}}$ \\
\hline $\begin{array}{l}\text { H5b: SMEs in the other EU countries } \\
\text { have better loan conditions than SMEs in } \\
\text { Slovakia. }\end{array}$ & 6.9037 & 0.141065 & 12.8419 & $\underline{\mathbf{0 . 0 4 5 6 1 7 < 0 . 0 5}}$ \\
\hline
\end{tabular}

\section{Sources: own processing}

In a majority of cases, our results confirmed that the firm's size has a significant impact on the perception of the funding risk, resp. that smaller companies perceive the funding risk more intensively than the larger ones. This finding in conformal with the results of the other authors, including Jakubec et al. (2012) and Sobeková (2011). Dong and Men (2014) informed that smaller and young companies face more financing constraints. The availability of credit information and the bank concentration ratio have a significant impact on SMEs financing. Cheng, Tang and Shi (2012) and Majková (2008) presented a weak capital power and a credit degree as the biggest problems for SMEs financing. Rostamkalaei and Freel (2015), Oliveira and Fortunato (2006), Bottazzi et al. (2014), Bougheras et al. (2006) considered the firm's size for a relevant factor affecting the funding risk of a company.

The impact of the age on the funding risk is not so obvious as in the case of the firm's size, because its impact was confirmed only partially. The studies of the other foreign authors are also contradictory. Arenius and Minniti (2005), Bonte et al. (2007), Brunow and Hirte (2006) and Levesque and Minniti (2011) brought the evidence that the age of the owner is a significant factor, that is affecting the business. The data from our research state that older entrepreneurs feel themselves more threatened in case of the funding risk than their younger colleagues. Neuberger and Räthke-Döppner (2014) brought an interesting evidence, that in case of Germany young entrepreneurs are more likely to pay higher interest rates because their businesses are smaller and their ability to pay at the time is lower than in case of the older 
entrepreneurs due to the liquidity reasons. This fact could also indicate that younger entrepreneurs should feel more threatened by the funding risk than the older ones. Oliveira and Fortunato (2006) stated that a credit rejection or the higher interest rates are most common in case of smaller firms with the younger owners. Werner and Faulenbach (2008) confirmed that age has an impact on the funding risk, resp. the young entrepreneurs face the funding risk more frequently than their older colleagues. Bottazzi et al. (2014) and Bougheas et al. (2006) bring the evidence that younger and smaller companies face the funding credit risk more intensively and that they have fewer options for the financing of their companies then the firms with the older owners. Unlike all the presented studies, our results show that the companies with the younger owners (mostly small companies with a short period of existence) feel more comfortable and are significantly more self-confident in case of the potentially negative influence of the funding risk on their companies than their older colleagues.

Our results are also contrary to the study realized among Slovenian businesses by Slavec (2014), who stated that the age of the entrepreneur has no significant impact on bank loans or trade credits, while such factor as the level of education does play a significant role in case of the bank loans.

The results of our research clearly indicate that smaller companies are experiencing significantly more problems with the obtaining of bank financing, are facing the more intensive impact of the funding risk, and perceive the loan criteria to be quite difficult to fulfil. Many authors declare that SMEs are a backbone of the market economy, resp. that they are one of the most important components of all world economies (Sobeková 2011, Karpak and Topcu 2010, Badulescu 2010, Henderson and Weiler 2010, Bhaird 2010, etc.). The results of this research should warn the governmental officials of Slovakia, and make them think about setting up the specific forms of support of this sector of the economy to achieve a sustainable economic growth. The quotation "think in small" is very important. Slovakia needs to prepare more efficient supporting tools to help SMEs to overcome the difficulties related to their financing, which is the main engine of their growth. Effective state support of small or micro companies may bring a very good result. We see the solution in the supporting schemes with the accent on microfinance (5000-15000 eur) or guarantee schemes with the participation of the private sector. The key attribute of this too is low bureaucracy, the online agreement process and a small interest rate. Next was how to support small and young companies is venture capital. It is a special type of finance for innovative companies. But in this field is still very poor information and state support. The government can support this type of project through venture capital funds and business angel nets.

Conclusion. The aim of the paper was to investigate the impact of a size of the company and an age of the owner on the perception of the funding risk in the segment of small and medium-sized enterprises in Slovakia in response to the restraints in their access to credit finance and to specify the importance of these factors in relation to the selected aspects of the funding risk. The data were analyzed by Pearson's chi-square statistics, which allowed to confirm the existence of the statistically significant dependencies between the chosen factors and the perception of the funding risk.

We have found that smaller companies do perceive the funding risk more intensively than larger companies. Entrepreneurs of the age between 36 and 45 declared the highest rejection rate of the loan applications. The impact of the size of the company on the frequency of bank loans rejection during the last 5 years was not statistically significantly confirmed. The statistically significant impact of the selected factors on the frequency of bank loans rejection was confirmed only in case of the age of the owner, but not in case of the size of the company. We can declare that a credit rejection is most common in case of younger business owners, but is not typical for the smaller companies.

In the group of entrepreneurs aged between 36 and 45 years the most frequent reason was related to the negative values of the financial indicators, and in case of the oldest entrepreneurs the most often reasons of the rejection of the loan application were the lack of collateral, poor business plan and negative values of the financial indicators. The results of the research confirm the existence of the statistically 
significant dependence between the age of the owner and the size of the company and the reasons for the rejection of bank loans application. General results show that most of the business owners regardless of their age are quite a sceptic about the effort of the banks to accept their needs, but the bigger the company is, the lower is the level of consent with this statement.

We would like to expand the focus of our further research on investigating the impact of the other relevant factors influencing all aspects of the financial risk of the company in the SME segment in the countries of the V4. The research team is aware of a certain degree of limitation of research results, especially in terms of the number of respondents, forms of the research implementation, and geographic targeting only on Slovak territory, and plans to remove them in the future by expanding the research to a larger number of Central European countries.

Funding. This research paper was funded from the project titled "SMEs in Slovakia - financial and credit risks" in the frame of the granting program of the Grant Agency of Academic Alliance.

\section{References} 247.

Arenius, P. and Minniti, M. (2005). Perceptual Variables and Nascent Entrepreneurs. Small Business Economics, Vol. 24, 233-

Badulescu, D. (2012). SMEs financing: The Extend of Need and the Responses of Different Credit Structures. Theoretical and Applied Economics, 17(7), 25-36

Behr, P., Guttler, A. (2007). Credit Risk Assessment and Relationship Lendng: An Empirical Analysis of German Small and Medium-Sized Enterprises. Journal of Small Business Management, 45 (2), 194 - 213.

Behr, P., Norden, L., Noth, F. (2013). Financial Constraints of Private Firms and Bank Lending Behavior. Journal of Banking and Finance, 37, 3472-3458

Belás, J., Bilan, Y., Ključnikov, A., Vincúrová, Z., Machaček, J. (2015) Actual Problems Of Business Risk In Sme Segment. Case Study From Slovakia. International Journal of Entrepreneurial Knowledge. 1/2015, v3. DOI: 10.1515/ijek-2015-0010.

Belas, J., Sopkova, G. (2016). A model of entrepreneurial orientation. Transformations in Business and Economics, 15(2B), 630-644.

Belás, J., Vojtovič, S., Ključnikov, A. (2016). Microenterprises and significant risk factors in loan process. Economics and Sociology, 9(1), 43-59. doi:10.14254/2071-789X.2016/9-1/3

Bena, J., Ondko, P. (2012). Financial development and the allocation of external finance. Journal of Empirical Finance, 19(1), $1-25$

Bitler, M.P., Robb, A.M., Wolken, J.D., (2001). Financial Services Used by Small Businesses: Evidence from the 1998 Survey of Small Business Finances. Federal Reserve Bulletin, April, 183-205

Bhaird, C.M. (2010). Resourcing Small and Medium Sized Enterprises. Springer Verlag: Berlin, 2010.

Bougheas, S., Mizen, P., Yalcin, C. (2006). Access to external finance: Theory and evidence on the impact of monetary policy and firm-specific characteristics. Journal of Banking and Finance, 30(1), 199-227

Bonte, W., Falck, O. and Heblich, H. (2007). Demography and Innovative Entrepreneurship. The Jena Economic Research papers, 2007-084. 116

Bottazzi, G., Secchi, A., Tamagni, F. (2014). Financial constraints and firm dynamics. Small Business Economics, 42(1), 99-

Brunow, S. and Hirte, G. (2006). Age Structure and Regional Economic Growth. Review of Regional Research, 26, 3-26

Cepel, M., Stasiukynas, A., Kotaskova, A., Dvorsky, J. (2018). Business Environment Quality Index in the SME Segment. Journal of Competitiveness, Vol. 10, Issue 1, pp. 21-40. DOI: 10.7441/joc.2018.02.02

Cheng, ME, Tang, Y. (2012). Research on the Small and Medium-sized Enterprises Financing Problems. Proceedings of the sixth international symposium - The development of small and medium-sized enterprises, Dec 15 - 19, 93-97.

Colombo, M., Cumming, D. J., Vismara. S. (2016). Governmental venture capital for innovative young firms. The Journal of Technology Transfer, 41(10), pp. 10-24. DOI:10.1007/s10961-014-9380-9.

Dobeš, K., Kot, S., Kramoliš, J., Sopková, G. (2017). The Perception of Governmental Support in The Context of Competitiveness of SMEs in the Czech Republic. Journal of Competitiveness, Vol. 9, Issue 3, pp. 34-50. DOI: 10.7441/joc.2017.03.03 149

Dong, Y., Men, Ch. (2014) SME financing in emerging markets. Emerging Markets Finance \& Trade,Jan/Feb2014, 50(1), 120-

Fetisovová, E., Hucová, E., Nagy, L., Vlachynský, K. (2012) Aktuálne Problémy financií malých a stredných podnikov. Bratislava: Ekonóm.

Henderson, J., Weiler, S. (2010). Entrepreneurs and job growth: probing the boundaries of time and space, Economic Development Quarterly, 24(1), 23 - 32. 
Hernández-Cánovas, G., Martínez-Solano, P. (2010). Relationship lending and SME financing in the continental European bank-based system. Small Business Economics. 34(4), pp. 465-482

Gambini, A, Zazzaro, A. (2013) Long-lasting bank relationships and growth of firms. SmallBusEcon, 40, 977-1007.

Hajduová, Z., Andrejkovič, M., Mura, L. (2014) Utilizing experiments designed results during error identification and improvement of business processes. Acta Polytechnica Hungarica, Vol. 11, No. 2, 2014, pp. 149-166 ISSN 1785-8860

Irwin, D. and Scott, J.M., (2010). Barriers faced by SMEs in raising bank finance.International Journal of Entrepreneurial Behavior and Research, 16(9), 245-259.

Jakubec, V., Sobeková Majková, M. Solik, J. (2012). Potreby mladých podnikatelov a prekážky vich podnikaní. ZMPS: Bratislava. ISBN 978-80-970916-4-4.

Karpak, B., Topcu, I. (2010). Small medium manufacturing enterprices in Turkey: an analytic network process framework for prioritizing factors affecting success. International Journal of Production Economics, 125, 60 - 70.

Ključnikov, A., Belás, J. (2016). Approaches of Czech Entrepreneurs to Debt Financing and Management of Credit Risk. Equilibrium. Quarterly Journal of Economics and Economic Policy, 11(2), 343-365. DOI: http://dx.doi.org/10.12775/ EQUIL.2016.016 Ključnikov, A., Belás, J., Smrčka, L. (2016a). The role of risk-taking and competitive aggressiveness in management of SMEs. Polish Journal of Management Studies, 14(1), 129-139. doi:10.17512/pjms.2016.14.1.12

Ključnikov, A., Belás, J., Kozubíková, L., Paseková, P. (2016b). The Entreprenurial Perception of SME Business Environment

Quality in the Czech Republic. Journal of Competitiveness, Vol. 8, Issue 1, pp. 66-78. DOI: 10.7441/joc.2016.01.05

Kozubíková, L., Homolka, L., Kristalas, D. (2017). The Effect of Business Environment and Entrepreneurs' Gender on Perception of Financial Risk in The Smes Sector. Journal of Competitiveness, Vol. 9, Issue 1, pp. 36-50. DOI: 10.7441/joc.2017.01.03 Kozubíková, L., Dvorský, J., Cepel, M. \& Balcerzak, A. P. (2017). Important characteristics of an entrepreneur in relation to risk

taking: Czech Republic case study. Journal of International Studies, 10(3), 220-233. doi:10.14254/2071-8330.2017/10-3/16 Lazányi, K. (2014). Entrepreneurs of the future. Serbial Journal of Management, 9(2), 149-158

Levesque, M. and Minniti, M. (2011). Age Matters: How Demographics Influence Aggregate Entrepreneurship.Strategic Entrepreneurship Journal, 5, 255-284.

Majková, M. (2008). Možnosti financovania malých a stredných podnikov v SR (Analýza štandardného a alternatívneho financovania malých a stredných podnikov v podmienkach SR). Tribune: Brno. ISBN 978-80-7399-590-4.

Mercieca, S., Schaeck, K., Wolfe, S. (2009). Bank Market Structure Competition and SME Financing Relationship in European

Regions. Journal of Financial Services Research, 36 (2-3), 137-155.

Mentel, G., Brożyna, J. (2015), Compatibility of market risk measures, Journal of International Studies, 8(2), 52-62. DOI:

$10.14254 / 2071-8330.2015 / 8-2 / 5$

Mura, L., Gašparíková, V. (2010). Penetration of small and medium sized food companies on foreign markets. Acta Universitatis Agriculturae Et Silviculturae Mendelianae Brunensis, 58(3), 157-163.

Neuberger, D., Räthke-Döppner, S. (2014). The role of demographic in small business loan pricing. Small Business Economics, $44(2), 411-424$

Oliveira, B., Fortunato, A. (2006). Firm Growth and Liquidity Constraints: A Dynamic Analysis. Small Business Economics, (27)2-3, 139-156

Pickernell, D., Packham, G., Jones, P., Miller, C., Thomas, B. (2011). Graduate entrepreneurs are different: They access more resources? International Journal of Entrepreneurial Behaviour and Research, 17(2), pp. 183-202.

Rabbani, K., Moossa, M. (2014) Non-accessibility of Bank Financing to Newly Established SMEs. Pakistan Business Review, 16(2), 293-305

Riding, A., Orser, B.J., Spence, M., Belanger, B. (2012). Financing new venture exporters. Small Business Economics, 38(2), pp. $147-163$

Rostamkalaei, A., Freel, M. (2015). The cost of growth: small firms and the pricing of bank loans. Small Business Economics, $46(2), 255-272$

Seo, J. (2013). Are bank loans to SMEs procyclical? Evidence from an analysis of the lending behaviour of Korean banks. South African Journal of Business Management, $44(2), 67-86$

Shi, L. (2012.) The Factors of Affecting Financing and Countermeasures Based on Asymmetric Information and Marginal Information Cost. Information and Business Intelligence, PTI 267, 672-677.

Slavec, A. (2014). Bank financing and trade credit use of Slovenian small firms: An empirical examination. Transformations in Business and Economics, 13(2), 91-101

Slovak Business Agency (2016). SMEs Report 2015. Online available: http://www.sbagency.sk/sites/default/files/sprava_0_stave_msp_2015.pdf (7.3.2017)

Simo, D., Mura, L., Buleca, J. (2016). Assessment of milk production competitiveness of the Slovak Republic within the EU-27 countries. Agricultural Economics-Zemedelska Ekonomika, Volume: 62, Issue: 10, pp. 482-492. ISSN 0139-570X

Sobeková Majková, M. (2011). Analýza bariér a faktorov financovania malých a stredných podnikov v SR. Journal of Economics, 59 (10), 1028-1032

Sobeková Majková, M. (2016). The Influence of the Selected Factors on Financial Risk Perception in Slovak SMEs. Actual problems of economics, 10(184), pp. $121-130$ 
Steinerowska-Streb, I., Steiner, A. (2014) An Analysis of External Availability on SMEs Decision Making. Thunderbird International Business Review, July/August 2014, 56(4), 373-386.

Vojtovič, S. (2016). The Impact of The Structural Funds on Competitiveness of Small and Medium-Sized Enterprises. Journal of Competitiveness, Vol. 8, Issue 4, pp. 30-45. DOI: 10.7441/joc.2016.04.02

Vos, E., Yeh, A. J.-Y., Carter, S., Tagg, S. 2007. The happy story of small business financing. Journal of Banking and Finance. 31(9), 2648-2672

Werner, A. \& Faulenbach, N. 2008. Das Gründungsverhalten Älterer: Eine empirische Analyse mit den Daten des Gründerpanels des IfM Bonn, If M-Materialien Nr. 184, Bonn, unter Mitarbeit von Brockmeyer, A.

O. Ключніков, Ph.D., доцент, Університет підприємництва та права (Чехія);

M. C. Майкова, Ph.D., Пан-європейський університет (Словаччина).

Сприйняття ризиків фінансування в малому та середньому бізнесі Словаччини: вплив віку власника та розміру компанії

Функціонування малих та середніх підприємств супроводжується низкою фінансових ризиків, які не характерні для великих компаній. При цьому, фінансові ризики виступають головним стримуючим фактором збільшення обсягу залучення зовнішніх інвестицій для фінансування зростання підприємства у майбутньому. У статті авторами визначено вплив розміру компанії та вік ії власника на сприйняття фінансових ризиків в умовах обмеженості кредитних ресурсів. Результати дослідження підтверджують вагомий вплив зазначених факторів на рівень фінансових ризиків малих та середніх підприємств Словаччини. У статті об'єктом дослідження було обрано 438 малих та середніх підприємств Словаччини, період проведення дослідження - 2016 рік. Результати тесту Пірсона Хі-квадрат підтверджують гіпотезу про наявність статистично значимоі залежності між обраними факторами та сприйняттям фінансових ризиків. Так, розмір компанії та вік ії власникає статистично значимими по відношенню до фінансових ризиків малих та середніх підприємств. Авторами встановлено, що менші за розміром компанії $\epsilon$ чутливішими до фінансових ризиків, аніж великі корпорації. 3 іншої сторони, результати дослідження підтверджують статистично значимий вплив вибраних факторів на частоту відмови від банківських кредитів лише за фактором - вік власника. Так, підприємці віком від 36 до 45 років отримують найбільшу кількість відмов у отриманні кредиту. Автори наголошують, що молоді підприємці більш самовпевнені та рішучіші у випадку настання можливих фінансових ризиків, аніж ї старші колеги. Результати дослідження також підтверджують наявність статистично значущої залежності між обраними факторами та причинами відмови у отриманні банківських кредитів. У роботі підтверджено гіпотезу, що відмова у кредитуванні найчастіше зустрічається серед молодих підприємців, але це не є характерним для невеликих компаній. Для підприємців віком від 36 до 45 років головною причиною у відмові кредитування $є$ негативні значення основних фінансових показників. При цьому для іншої аналізованої категорії підприємців (старші за віком) головними причинами відмови у кредитуванні стали: відсутність застави, низька якість бізнес-плану та негативні значення основних фінансових показників.

Ключові слова: кредитний ризик, малі та середні підприємства, вік, розмір, кредитне фінансування, банківське фінансування, зовнішні фінанси, доступ до фінансування.

Manuscript received: 13.10 .2018

(C) The author(s) 2018. This article is published with open access at Sumy State University. 